\title{
Publisher Correction: Stand age and species richness dampen interannual variation of ecosystem-level photosynthetic capacity
}

Talie Musavi, Mirco Migliavacca, Markus Reichstein, Jens Kattge, Christian Wirth, T. Andrew Black, Ivan Janssens, Alexander Knohl, Denis Loustau, Olivier Roupsard, Andrej Varlagin, Serge Rambal, Alessandro Cescatti, Damiano Gianelle, Hiroaki Kondo, Rijan Tamrakar and Miguel D. Mahecha

Correction to: Nature Ecology \& Evolution https://doi.org/10.1038/s41559-016-0048, published online 23 January 2017.

In the version of this Article originally published, the wrong Supplementary Information pdf was uploaded, in which the figures did not correspond with those mentioned in the main text and the R code was not presented properly. This has now been replaced.

Published online: 11 February 2019

https://doi.org/10.1038/s41559-019-0829-y 